Article

\title{
Stability of Slash Pine Families with Major Gene and Partial Resistance to Single-Gall and Mixed-Gall Inocula of Cronartium quercuum fusiforme in Greenhouse Studies
}

Karina P. Gramacho ${ }^{1}$, Robert A. Schmidt ${ }^{2, *}$ and Thomas Miller ${ }^{2}$

1 Plant Pathology Department, Cocoa Research Center, Executive Commission of the Plan for Cocoa Farming, Ex. PO 07, 45600-970, Itabuna, BA, Brazil; E-Mail: karina@cepec.gov.br

2 School of Forest Resources and Conservation, Institute of Food and Agricultural Sciences, University of Florida, P.O. Box 110410, Gainesville, FL 32611-0410, USA;

E-Mail: tm1266@cox.net

* Author to whom correspondence should be addressed; E-Mail: raschmidt@ifas.ufl.edu; Tel.: +1-352-332-3211; Fax: +1-352-392-1707.

Received: 27 April 2013; in revised form: 11 May 2013 / Accepted: 24 May 2013 /

Published: 20 June 2013

\begin{abstract}
Single-gall and mixed-gall inocula from fusiform rust (Cronartium quercuum fusiforme) galls in field studies were used in greenhouse tests to investigate their pathogenic variability and the temporal and spatial stability of fusiform rust incidence of resistant slash pine (Pinus elliottii var. elliottii) seedlings. Analyses of variance showed significant main effects for families and inocula and for the interactions of families and inocula indicating abundant pathogenic variation and differential family resistance. Averaged over all families and inocula, there were no significant differences between sequential inocula, i.e., inocula from successive generations of the pathogen. However, when analyzed separately Family R1 with segregated major gene resistance showed increased rust incidence with successive generations of the pathogen. Also Family R1 accounted for a major portion of the temporal (51.4\%) and spatial (49.6\%) interaction sum of squares. In contrast the other resistant families each accounted for a minor portion of this statistic. These results indicate pathogen virulence toward major gene resistance, possible selection for virulence and the relative instability of Family R1 compared with other resistance families.
\end{abstract}

Keywords: Pinus elliottii var. elliottii; fusiform rust; pathogen virulence 


\section{Introduction}

Fusiform rust caused by Cronartium quercuum (Berk.) Miyabe ex Shirai F. sp. fusiforme (Cqf) was of rare occurrence at the beginning of the 20th century, but reached epidemic proportions during the second half of the century [1]. The rapid increase and spread of fusiform rust through extensive areas of the southeastern USA was primarily due to anthropogenic factors associated with the intensive plantation culture of southern pines in the region [2,3]. Four decades of research and development have resulted in the successful deployment of rust-resistant pine families to significantly reduce losses to fusiform rust $[4,5]$. However, there is little information on the temporal and spatial stability of rust resistance in these open- or control-pollinated families or of their potential to select for virulent pathotypes. Stability is of special concern in this perennial crop species, since pathogenic variability appears great [6-9], and major genes in the host are associated with resistant loblolly pine [10] and slash pine [11,12] including Family R1 in this paper [13].

The objective of these four artificial inoculation tests was to assess the pathogenicity of temporally and spatially diverse single- and mixed-gall inocula on a small number of representative rust-resistant slash pine families with major gene resistance and partial resistance.

\section{Methods and Materials}

\subsection{Methods Common to All Experiments}

Rust incidence on pine seedlings was evaluated at the Resistance Screening Center, U. S. Department of Agriculture Forest Service, Bent Creek, NC, USA (RSC), using standard procedures of inoculation, data collection and statistical analyses [14]. Briefly, aeciospores are collected from pine galls, cleaned, and vacuum dried for storage. Basidiospore inocula are produced by spraying rehydrated aeciospores onto the undersides of succulent red oak (Quercus rubra L.) leaves. Six-week-old seedlings are spray-inoculated with an aqueous suspension of basidiospores (20,000 spores $/ \mathrm{mL})$, incubated for $24 \mathrm{~h}$ in a moist chamber $\left(21^{\circ} \mathrm{C},>97 \%\right.$ relative humidity) and placed in a greenhouse $\left(15-20{ }^{\circ} \mathrm{C}, 12 \mathrm{~h}\right.$ of fluorescent light, $30 \mathrm{ft}$ candles at plant height). In our tests, rust galls, without regard to their morphology, were recorded 6-9 month after inoculation and the percentage of seedlings with galls in each family was calculated from 2-6 replications of 20 seedlings each, inoculated on two successive days, a total of 40 or 120 seedlings/family/inoculum/day. The relative rust resistance of the pine families, recorded previously in extensive field tests, is shown in Table 1. 
Table 1. Relative fusiform rust resistance of progeny of slash pine families established in field tests in the Southeastern Coastal Plain.

\begin{tabular}{|c|c|c|c|c|c|}
\hline \multirow{4}{*}{ Family $^{c}$} & \multicolumn{5}{|c|}{ Field progeny tests } \\
\hline & \multicolumn{3}{|c|}{ CFGRP $^{a}$} & \multicolumn{2}{|c|}{ FBRC $^{b}$} \\
\hline & \multicolumn{2}{|c|}{ No. of tests ${ }^{d}$} & \multirow{2}{*}{$\mathbf{R 5 0}^{\mathrm{e}}$} & \multirow{2}{*}{ No. of OP tests } & \multirow{2}{*}{$\%^{f}$} \\
\hline & OP & $\mathbf{C P}$ & & & \\
\hline PR3 & 10 & 2 & -15.5 & -- & -- \\
\hline PR1 & 26 & 16 & 04.4 & 48 & 15.5 \\
\hline $\mathrm{R} 1$ & 17 & 3 & 04.8 & 39 & 20.0 \\
\hline $\mathrm{R} 4$ & 22 & 13 & 19.9 & 48 & 22.3 \\
\hline PR2 & 5 & 2 & 26.6 & 46 & 17.4 \\
\hline $\mathrm{S} 1$ & 8 & 0 & 83.4 & 36 & 74.5 \\
\hline $\mathrm{S} 2$ & 8 & 10 & 81.9 & 44 & 74.5 \\
\hline
\end{tabular}

${ }^{\text {a }}$ CFGRP $=$ Cooperative Forest Genetics Research Program, University of Florida; ${ }^{\mathrm{b}}$ FBRC $=$ Forest Biology Research Cooperative, University of Florida; tests established in sequential plantings from 1987-1994 at 12 locations in FL, GA, AL and $\mathrm{MS} ;{ }^{c} \mathrm{R}=$ resistant, $\mathrm{PR}=$ partially resistant, $\mathrm{S}=$ susceptible; ${ }^{\mathrm{d}} \mathrm{OP}=$ open-pollinated; $\mathrm{CP}=$ control pollinated; ${ }^{\mathrm{e}} \mathrm{R} 50=$ Best linear unbiased prediction (BLUP) of percentage trees infected in an environment where unimproved families have $50 \%$ of the trees infected; ${ }^{\mathrm{f}} \%$ trees with one or more galls.

Aeciospore inocula were collected from trees in field studies; either single-gall inocula from a known family or mixed-gall inocula from a mixture of single-galls. Aeciospore collections came from four locations in FL and GA (Figure 1); and when noted; collections were made in two time periods (T1 and T2) from galls initiated in different years in sequential plantings (Tests 1 and 2). Inocula used to challenge seedlings progeny of the family from which it was collected are referred to as "self-inocula".

Figure 1. Locations in the Southeastern Coastal Plain where aeciospores inocula were collected $(13,17,19,20)$ and where pine parents (R1, R4, PR1-3 and S1-2) were selected.

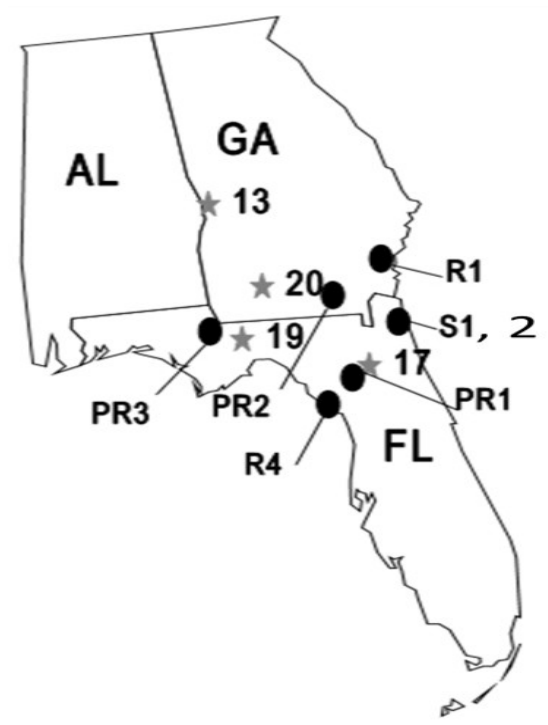




\subsection{Temporal Stability}

Test 1. Mixed-gall inocula from sequential plantings. Seedling progeny from four resistant (R1, R4, PR1, PR2) and one susceptible (S2) open-pollinated slash pine families were inoculated with eight (two time periods $\times$ four locations) inocula [15]. Inocula were mixtures of six galls, three each from two susceptible families (S1 and S2). The two time periods (T1 and T2) were represented by inocula from galls initiated in 1988-1989 and 1992-1993, respectively, from plantings established in 1987 and 1989. Three to five years (generations of the pathogen) elapsed between sequential inocula T1 and T2. The locations were 13, 17, 19 and 20 (Figure 1). The percentage of seedlings with galls (two replications of 20 seedlings/family/inoculum on each of two successive days) was examined by analysis of variance with a split plot, randomized complete block design. Inocula were whole plots and families were sub-plots. Families, inocula and locations were fixed effects.

Test 2. Family-specific single-gall and mixed-gall inocula from sequential plantings. Seedling progeny of four resistant (R1, R4, PR1, PR2) and one susceptible (S1) open-pollinated slash pine families were inoculated with single-gall and mixed-gall inocula from different time periods. Seedling progeny of each family were inoculated with (1) single-gall inocula from the same family (self-inocula) in time period one (T1) and two (T2), and (2) mixed-gall inocula (a mix of single-gall inocula from all families) from the two time periods. An average of 6 year (generations of the pathogen) elapsed between time period T1 and T2. Data on percentage seedlings with galls on six replications of 20 seedlings each/family/inoculum on two successive days were analyzed.

\subsection{Spatial Stability}

Test 3. Family-specific and location-specific single-gall inocula. Seedling progeny of three resistant (R1, R4, PR2) and one susceptible (S2) open-pollinated slash pine families were inoculated with 16 (four family-specific $\times$ four location-specific) single-gall inocula [14]. Family-specific inocula R1, R4 and PR2 and S2 were from their respective families at locations 13, 17, 19 and 20 (Figure 1). Experimental design data collection and statistical analyses were as described in Test 1.

Test 4. Mixed-gall and family-specific single-gall and mixed-gall inocula. Seedling progeny of five resistant (R1, R4, PR1, PR2, PR3) and one susceptible (S1) open-pollinated slash pine families were inoculated each with (1) five single-gall inocula (R1, R4, PR1, PR2, PR3) collected from their respective resistant families, (2) one single-gall inoculum (21-1) from a resistant loblolly pine family, and (3) two mixed-gall inocula (13-1 and 20-2) from resistant slash pine families (R1, R4, PR1, PR2, PR3) at locations 13 and 20 (Figure 1). Single-gall inocula were from location 19 (Figure 1). Data on percentage of seedlings with galls from six replications of 20 seedlings each/family/inocula on two successive days were examined by an analysis of variance in a randomized block factorial design.

\section{Results}

\subsection{Temporal Stability}

Test 1. Among families the average percentage of seedlings with galls differed significantly (Table 2), ranging from $44 \%$ (R1) to $94 \%$ (S2) for inocula $\mathrm{T} 1$ and $63 \%$ to $95 \%$, respectively, for 
inocula T2 (Table 3). While the main effects of inocula were not significantly different the family by inocula interactions were significantly different. Overall sequential inocula were not statistically different. However, when analyzed separately Family R1 had greater rust incidence from T2 inocula than from those of $\mathrm{T} 1$ at all four locations and the average (44\% for $\mathrm{T} 1$ and $63 \%$ for $\mathrm{T} 2$ ) was statistically significant, $p=0.05$ (Table 3). Other resistant families showed no such increase. Partitioning the interaction sum of squares among families (Table 4) showed that Family R1 accounted for nearly $50 \%$ of the variation.

Table 2. Summary of analyses of variance for four tests of the effect of inocula sources on the percentage of slash pine seedlings with galls when inoculated with basidiospores of Cronartium quercuum F. sp. fusiforme.

\begin{tabular}{|c|c|c|c|c|}
\hline & \multicolumn{4}{|c|}{ Test No. } \\
\hline & 1 & 2 & 3 & 4 \\
\hline & \multicolumn{4}{|c|}{ Inocula sources $^{\text {a }}$} \\
\hline & \multicolumn{2}{|c|}{ Temporal stability } & \multicolumn{2}{|c|}{ Spatial stability } \\
\hline & $\begin{array}{c}\text { Mixed-gall from } \\
\text { sequential } \\
\text { plantings }\end{array}$ & $\begin{array}{c}\text { Family-specific and } \\
\text { mixed galls from } \\
\text { sequential plantings }\end{array}$ & $\begin{array}{c}\text { Family-specific and } \\
\text { location-specific, } \\
\text { single-gall }\end{array}$ & $\begin{array}{c}\text { Mixed-gall and } \\
\text { family-specific } \\
\text { single-gall } \\
\end{array}$ \\
\hline No. of families & 5 & 5 & 4 & 6 \\
\hline No. of inocula & 8 & 12 & 16 & 8 \\
\hline \multicolumn{5}{|c|}{---------------------------------------------------Analysis of variance------------------------------------------------- } \\
\hline Source of variation & \multicolumn{4}{|c|}{ Statistical significance $^{\mathrm{b}}$} \\
\hline Family $(\mathrm{F})$ & $* * *$ & $* * *$ & $* * *$ & $* * *$ \\
\hline Inocula (I) & NS & $* * *$ & $*$ & $* * *$ \\
\hline Family inocula (FI) & & $* * *$ & NS & \\
\hline Location inocula (LI) & & & NS & \\
\hline Sequential inocula (SI) & NS & NS & & \\
\hline $\mathrm{F} \times \mathrm{I}$ & $* *$ & $* * *$ & $* *$ & $* * *$ \\
\hline $\mathrm{F} \times \mathrm{FI}$ & & $* * *$ & NS & \\
\hline $\mathrm{F} \times \mathrm{LI}$ & NS & & NS & \\
\hline $\mathrm{F} \times \mathrm{SI}$ & $* * *$ & NS & & \\
\hline $\mathrm{F} 1 \times \mathrm{SI}$ & NS & & NS & \\
\hline $\mathrm{L} 1 \times \mathrm{SI}$ & NS & & & \\
\hline $\mathrm{F} \times \mathrm{LI} \times \mathrm{SI}$ & NS & & & \\
\hline
\end{tabular}

${ }^{a}$ Family-specific inocula were derived from aeciospores collected from a single gall on a specific family as indicated in the test; location-specific inocula were derived from aeciospores collected from four locations as indicated in the text and represent spatial variation; inocula from sequential plantings were collected from galls of different ages in adjacent plantations and represent temporal variation. Mixed-gall inocula were produced by combining aeciospores from single gall collections; ${ }^{\mathrm{b}} *, * *$, and $* * *$ give statistical significance at the $p=0.05,0.01$ and 0.001 level, respectively; NS $=$ non-significant. 
Table 3. The percentage of slash pine seedlings with galls after inoculation with basidiospores from mixed-gall sources of Cronartium quercuum F. sp. fusiforme from sequential plantings representing temporal variation.

\begin{tabular}{|c|c|c|c|c|c|c|c|c|c|c|}
\hline \multirow[b]{3}{*}{ Family $^{b}$} & \multicolumn{10}{|c|}{ Inocula source $^{\text {a }}$} \\
\hline & \multicolumn{2}{|c|}{$13^{\mathrm{c}}$} & \multicolumn{2}{|c|}{17} & \multicolumn{2}{|c|}{19} & \multicolumn{2}{|c|}{20} & \multicolumn{2}{|c|}{ Average } \\
\hline & $\mathrm{T} 1^{\mathrm{d}}$ & $\mathrm{T} 2$ & $\mathrm{~T} 1$ & $\mathrm{~T} 2$ & $\mathrm{~T} 1$ & $\mathrm{~T} 2$ & $\mathrm{~T} 1$ & $\mathrm{~T} 2$ & $\mathrm{~T} 1$ & $\mathrm{~T} 2$ \\
\hline R1 & $39^{e, f}$ & 60 & 41 & 50 & 53 & 66 & 42 & 77 & 44Bc & 63Ad \\
\hline $\mathrm{R} 4$ & $74^{c}$ & 71 & 84 & 67 & 72 & 79 & 69 & 85 & $74 \mathrm{Ab}^{\mathrm{f}}$ & $75 \mathrm{Ac}$ \\
\hline PR1 & 91 & 87 & 86 & 78 & 91 & 90 & 87 & 96 & 89Aa & 88Aab \\
\hline PR2 & 92 & 83 & 93 & 83 & 89 & 88 & 97 & 85 & 93Aa & $85 B b$ \\
\hline S2 & 95 & 94 & 94 & 98 & 91 & 97 & 96 & 91 & 94Aa & 95Aa \\
\hline Average & 78 & 79 & 80 & 75 & 79 & 84 & 79 & 87 & 79A & $81 \mathrm{~A}$ \\
\hline
\end{tabular}

${ }^{a}$ Six-gall mix of aeciospores, three galls from each of two susceptible families (S1-2); ${ }^{b}$ Open-pollinated families: $\mathrm{R}=$ resistant, $\mathrm{PR}=$ partially resistant, $\mathrm{S}=$ susceptible; $^{\mathrm{c}}$ Locations in $\mathrm{FL}$ and GA, see Figure $1 ;{ }^{\mathrm{d}} \mathrm{T} 1$ and T2 = inocula from galls produced in sequential plantings in 1988-1989 and 1992-1993, respectively; ${ }^{\mathrm{e}}$ Average of 80 seedlings (two replications of 20 seedlings/each on two successive days); ${ }^{\mathrm{f}}$ Unlike upper case letters indicate statistical significance $(p=0.05)$ between time periods T1 and T2; unlike lower case letters indicate statistical significance among families within time periods.

Table 4. Percent contribution of family to the interaction sum of squares for percentage of galls on slash pine seedling inoculated with basisiospore inocula of Cronartium quercuum F. sp. fusiforme.

\begin{tabular}{ccc}
\hline \multirow{2}{*}{ Family $^{\text {a }}$} & \multicolumn{2}{c}{ Interaction $^{\mathbf{b}}$} \\
\cline { 2 - 3 } R1 & $\mathbf{F} \times \mathbf{L I}^{\mathbf{b}}$ & $\mathbf{F} \times \mathbf{L I} \times \mathbf{S I}$ \\
\hline PR1 & $\mathbf{5 1 . 4}$ & $\mathbf{4 9 . 6}$ \\
S2 & 14.7 & 5.5 \\
R4 & 9.3 & 5.4 \\
PR2 & 7.4 & 9.9 \\
& 4.1 & 22.3 \\
\hline
\end{tabular}

${ }^{\mathrm{a}} \mathrm{R}=$ resistant, $\mathrm{PR}=$ partially resistant, $\mathrm{S}=$ susceptible; ${ }^{\mathrm{b}} \mathrm{F}=$ family, $\mathrm{LI}=$ location inocula, $\mathrm{SI}=$ sequential inocula.

Test 2. The average rust incidence varied significantly $(p=0.001)$ among families (Table 2) ranging from $48 \%(\mathrm{R} 1)$ to $89 \%(\mathrm{~S} 2)$ (Table 5$)$. The mixed-gall inocula resulted in significantly more rust (78\%) compared with single-gall inocula (70\%). However, in only 1 of 10 comparisons between T1 and T2 was there a significant difference within a family, and here (PR1) the T2 inocula caused significantly less rust (58\%) than the $\mathrm{T} 1$ inocula (76\%) (Table 5). The $\mathrm{F} \times \mathrm{I}$ and $\mathrm{F} \times \mathrm{FI}$ interactions were significant ( $p=0.001$ ) (Table 2). The percentage of seedlings with galls averaged near $50 \%$ for Family R1, typical for an open-pollinated major gene resistant family where the mother tree is heterozygous for the major gene and when virulence against the major gene is low or absent in the inocula. 
Table 5. The percentage of slash pine seedlings with galls after inoculation with basidiospores from family-specific single-gall and mixed-gall sources of Cronartium quercuum F. sp. fusiforme from sequential plantings, representing temporal variation.

\begin{tabular}{|c|c|c|c|c|c|}
\hline \multirow[b]{3}{*}{ Family $^{b}$} & \multicolumn{4}{|c|}{ Inocula $^{a}$} & \multirow[b]{3}{*}{ Average } \\
\hline & \multicolumn{2}{|c|}{ Family specific } & \multicolumn{2}{|c|}{ Mixed } & \\
\hline & $\mathrm{T} 1$ & $\mathrm{~T} 2$ & $\mathrm{~T} 1$ & $\mathrm{~T} 2$ & \\
\hline R1 & $\mathbf{5 0} \mathbf{A}^{\mathrm{c}, \mathrm{d}}$ & $44 A$ & $51 \mathrm{~A}$ & $46 A$ & $48 c$ \\
\hline $\mathrm{R} 4$ & $68 \mathrm{~A}$ & $78 \mathrm{~A}$ & $78 \mathrm{~A}$ & $77 \mathrm{~A}$ & $76 b$ \\
\hline PR1 & $76 \mathrm{~A}$ & $58 \mathrm{~B}$ & $85 \mathrm{~A}$ & $81 \mathrm{~A}$ & $75 b$ \\
\hline PR2 & $81 \mathrm{~A}$ & $76 \mathrm{~A}$ & $82 \mathrm{~A}$ & $85 \mathrm{~A}$ & $81 \mathrm{~b}$ \\
\hline S2 & $80 \mathrm{~A}$ & $87 \mathrm{~A}$ & $96 \mathrm{~A}$ & $94 \mathrm{~A}$ & $89 a$ \\
\hline Average & $71 \mathrm{~A}$ & $69 \mathrm{~A}$ & $78 \mathrm{~A}$ & $77 \mathrm{~A}$ & 74 \\
\hline Grand average & \multicolumn{2}{|c|}{$70 \mathrm{~B}$} & \multicolumn{2}{|c|}{$78 \mathrm{~A}$} & \\
\hline
\end{tabular}

${ }^{a}$ Family-specific inocula were derived from aeciospores collected from a single gall of the family designated; mixed inocula were derived from aeciospores from all families. T1 and T2 were collected from galls initiated in 1987-1992 and 1991-1996 in sequential plantings; ${ }^{\mathrm{b}}$ Open-pollinated families; $\mathrm{R}=$ resistant, $\mathrm{PR}=$ partially resistant, $\mathrm{S}=$ susceptible; $^{\mathrm{c}}$ Average of 240 seedlings (six replications of 20 seedlings each) on two successive days; ${ }^{\mathrm{d}}$ Unlike upper case letters indicate statistical significance between time periods $\mathrm{T} 1$ and $\mathrm{T} 2$ inocula within family specific or mixed inocula, or in the grand average between family-specific and mixed gall inocula; unlike lower case letters indicate statistical significance among families, $p=0.05$.

\subsection{Spatial Stability}

Test 3. The main effects of family and inocula and their interaction were statistically significant (Table 2). As shown in Figure 2, family means varied from 53\% (R1) to 95\% (S2). Across the sixteen inocula, Family R1 exhibited the greatest variation, ranging from $35 \%$ for isolate $17 \mathrm{C}$ to $76 \%$ for isolate 20D (Figure 2). Two isolates 20D and 19C caused unusually high rust incidence on Family R1 (Figure 2). Family R1 contributed most to the interaction sum of squares; 34.6, 47.9 and 50.4\% for the family-by-family isolate, family-by-location isolate and family-by-isolate, respectively (Table 6).

Table 6. Percent contribution of family to the interaction sum of squares for slash pine seedlings inoculated with basidiospores of Cronartium quercuum F. sp. fusiforme.

\begin{tabular}{cccc}
\hline \multirow{2}{*}{ Family $^{\mathbf{b}}$} & \multicolumn{3}{c}{ Interactions $^{\mathbf{a}}$} \\
\cline { 2 - 4 } & $\mathbf{F} \times \mathbf{F I}$ & $\mathbf{F} \times \mathbf{L I}$ & $\mathbf{F} \times \mathbf{I}$ \\
\hline & $-\mathbf{3 4 . 6}$ & $\mathbf{4 7 . 9}$ & $\mathbf{5 0 . 4}$ \\
R1 & 08.9 & 38.3 & 23.9 \\
PR2 & 28.4 & 2.8 & 10.2 \\
S2 & 28.0 & 11.0 & 15.5 \\
\hline
\end{tabular}

${ }^{\mathrm{a}} \mathrm{F}=$ family, $\mathrm{FI}=$ family inocula, $\mathrm{LI}=$ location inocula, $\mathrm{I}=$ inocula $;{ }^{\mathrm{b}} \mathrm{R}=$ resistant, $\mathrm{PR}=$ partially resistant, $\mathrm{S}=$ susceptible. 
Figure 2. Percentages of seedlings with rust galls (PGAL) on progeny of four slash pine families (R1, R4, PR2, S2) six months after inoculation with basidiospores from 16 isolates (inocula) of C. quercuum F. sp. fusiforme. Isolates are identified by location (\#13, 17, 19, $20)$ and family $(\mathrm{R} 1=\mathrm{A}, \mathrm{R} 4=\mathrm{B}, \mathrm{PR} 2=\mathrm{C}$ and $\mathrm{S} 2=\mathrm{D})$. Each datum point is the average of 80 seedlings (two replications of 20 seedlings each/family/inoculation on two successive days). Mean separation $(\cdot-\cdot) p=0.05$.
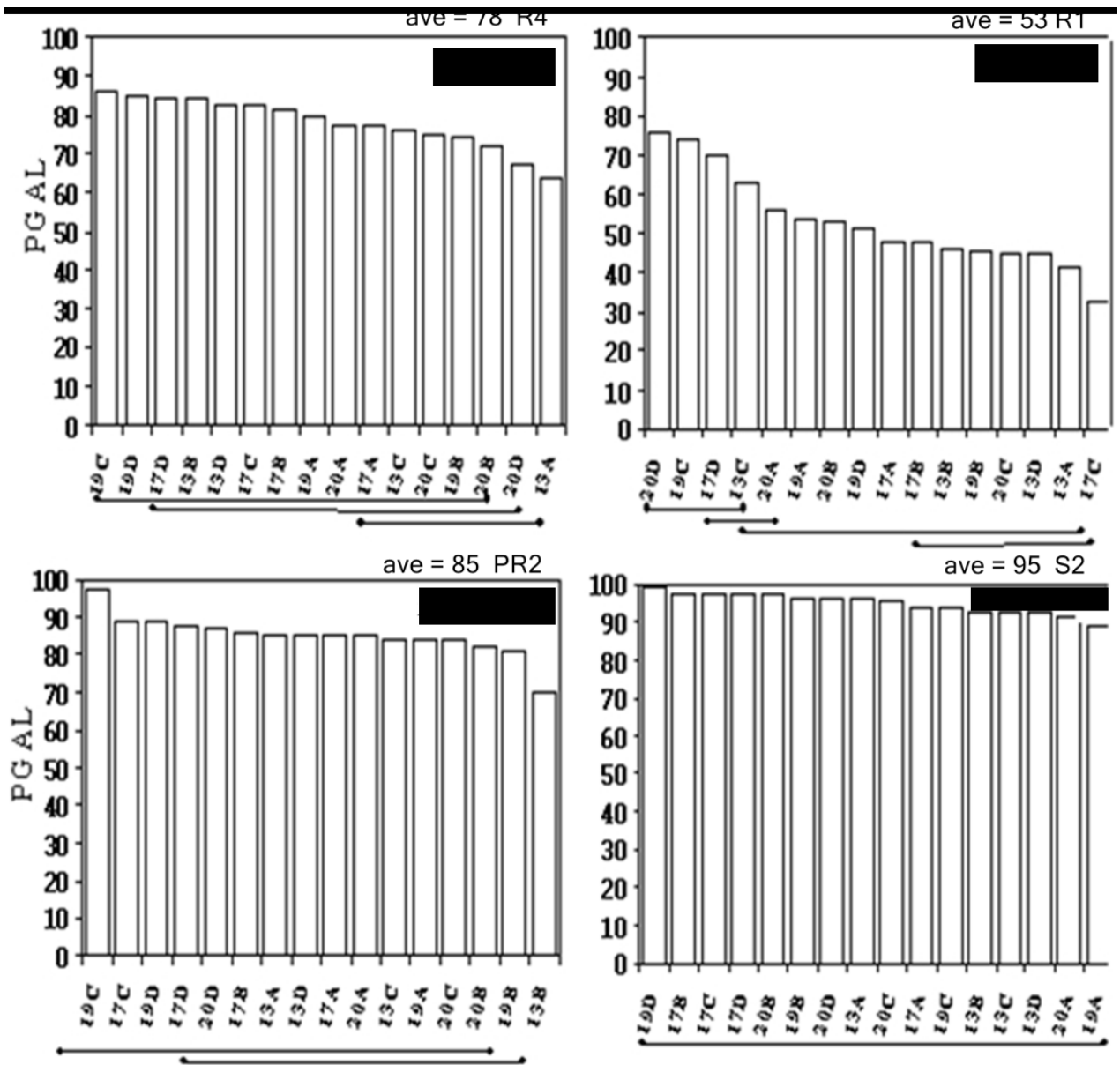

Test 4. Rust incidence varied significantly $(p=0.001)$ among resistant families, inocula and their interaction (Table 2). Family rust incidence varied from $58 \%$ (R1) to $89 \%$ (PR2) and inocula varied from $67 \%$ to $82 \%$, with the highest incidence resulting from the mixed inocula sources (Table 7). Rust incidence on the susceptible family S1 averaged 96\%. Significantly the self-inoculum from Family R1 caused the greatest rust incidence on family R1 (72\%) compared with other single gall inocula (average 53.4\%). We suggest the R1 inoculum may have come from an Rr tree. 
Table 7. The percentage of slash pine seedlings with galls when inoculated with basidiospores from six family-specific single-gall and two mixed-gall sources of Cronartium quercuum F. sp. fusiforme.

\begin{tabular}{cccccccccc}
\hline & \multicolumn{10}{c}{ Inocula source $^{\text {a }}$} \\
\cline { 2 - 11 } & Family-specific single gall & \multicolumn{3}{c}{ Mixed-gall } \\
Family & PR3 & PR2 & PR1 & R1 & R4 & $21-1$ & $20-2$ & $13-1$ & Ave. \\
PR1 & $\mathbf{5 7 B c d}$ & $\mathbf{6 2 A B c}$ & $\mathbf{5 5 B c}$ & $\mathbf{7 2 A b c}$ & $\mathbf{4 0 C c}$ & $\mathbf{5 3 B d}$ & $\mathbf{7 2 A b}$ & $\mathbf{5 2 B c}$ & $\mathbf{5 8 e}$ \\
PR2 & $65 \mathrm{BCbc}$ & $79 \mathrm{Ab}$ & $84 \mathrm{Aa}$ & $75 \mathrm{ABb}$ & $76 \mathrm{Aab}$ & $62 \mathrm{Cc}$ & $78 \mathrm{Ab}$ & $82 \mathrm{Aab}$ & $\mathbf{7 5 c}$ \\
PR3 & $85 \mathrm{BCa}$ & $91 \mathrm{ABa}$ & $89 \mathrm{ABa}$ & $87 \mathrm{ABa}$ & $85 \mathrm{BCa}$ & $89 \mathrm{ABa}$ & $96 \mathrm{Aa}$ & $91 \mathrm{ABa}$ & $\mathbf{8 9 a}$ \\
R4 & $54 \mathrm{Cd}$ & $63 \mathrm{Bc}$ & $71 \mathrm{ABb}$ & $64 \mathrm{Bc}$ & $68 \mathrm{Bb}$ & $75 \mathrm{ABb}$ & $80 \mathrm{Ab}$ & $78 \mathrm{ABb}$ & $\mathbf{6 9 d}$ \\
Ave. $(\mathrm{R} \& \mathrm{PR})$ & $73 \mathrm{BCb}$ & $78 \mathrm{BCb}$ & $71 \mathrm{Cb}$ & $80 \mathrm{ABCab}$ & $77 \mathrm{BCab}$ & $89 \mathrm{Aa}$ & $82 \mathrm{ABb}$ & $85 \mathrm{ABab}$ & $\mathbf{8 0 b}$ \\
$\mathrm{S} 1$ & $67 \mathrm{D}$ & $75 \mathrm{~B}$ & $74 \mathrm{BC}$ & $76 \mathrm{~B}$ & $69 \mathrm{CD}$ & $74 \mathrm{BC}$ & $82 \mathrm{~A}$ & $78 \mathrm{AB}$ & $\mathbf{7 4}$ \\
\hline
\end{tabular}

${ }^{a}$ Family-specific inocula derived from aeciospores collected from a single gall on the family designated (21-1 was collected from a loblolly family); mixed-gall inocula were a mixture of family single gall inocula (excluding PR3 and 21-1) from locations 13 and 20 (refer to Figure 1); ${ }^{\mathrm{b}}$ Open-pollinated families $\mathrm{R}=$ resistant, $\mathrm{PR}=$ partially resistant, $\mathrm{S}=$ susceptible; ${ }^{\mathrm{c}}$ Average percentage of 240 seedlings (six replications of 20 each) on two successive days; ${ }^{\mathrm{d}}$ Unlike upper case letters indicate statistical significance among isolates within a family (rows); unlike lower case letters indicate statistical significance among families within isolates (columns) $p=0.05$.

\section{Discussion}

Inoculations at the RSC of rapidly-growing, succulent slash pine seedlings in optimum conditions of temperature and moisture, with 20,000 spores/mL resulted in multiple host reaction types and much higher disease incidence than typically recorded in field studies. For example, hypersensitive-like stem lesions recorded at the RSC are not recorded in field progeny tests. An RSC performance index, which adjusts for resistant reaction types, provides a good correlation of family resistance rankings between field and greenhouse tests [16]. The resistant families which averaged less than $20 \%$ rust incidence in field tests (Table 1) averaged approximately $74 \%$ at the RSC (Tables 3, 5 and 7).

The 32 single-gall and 20 mixed-gall inocula in these tests represent a small sample of the wild type Cqf pathogen population. The five resistant and one susceptible open-pollinated slash pine families, although extensively tested in field [17,18] and greenhouse studies [19] are also a small sample. Even so the statistically significant main effects of families and isolates and the many statistically significant interaction effects of families and isolates (Table 2) confirm the pathogenic variability reported by others [6-9] and also suggest differential types of resistance among families.

When these studies were begun little was known about the nature of rust resistance in slash pine. Results from field tests and greenhouse tests led to research identifying a major gene for rust resistance segregating in Family R1 [13] and partial resistance in family PR1, PR2 and PR3 [20]. Interpreting our data with these earlier findings reveals evidence for the occurrence of virulence toward the major gene resistance in Family R1. For example, inocula collected from Family R1 in field studies caused significantly greater rust incidence (\% seedlings with galls) on Family R1 (72\%) than did the other single gall inocula (ave. 53.4\%) (Table 7). However, there is only a 50/50 probability that the "virulent" inoculum was collected from the resistant genotype "Rr" as opposed to the susceptible 
genotype "rr" in this segregating open-pollinated pine family. If inoculum was collected from the "Rr" genotype results could indicate a selection for virulence by Family R1. Also inocula collected from location twenty at time period two (20-2) (Table 7) caused greater rust incidence on Family R1, suggesting a higher incidence of the virulent pathotypes(s) in this inoculum.

Further evidence for virulence toward Family R1 is shown in Table 3 where sequential inocula from time period T2 caused greater rust incidence at the four locations and on average T2 (63\%) was significantly greater $(p=0.05)$ than was inocula from T1 $(44 \%)$. Inocula T2 was a mix of six galls each from the two very susceptible families, S1 and S2, likely susceptible to most pathotypes including that virulent to Family R1. This increase in rust incidence on Family R1 could indicate a selection for virulence by Family R1 or perhaps a recombination of genes during pathogen meiosis on oak. In contrast, partially resistant families on average showed no significant increase in rust incidence with sequential inocula since partially resistant families do not exert strong selection pressure on the pathogen. Family R1 accounted for nearly $50 \%$ of the temporal and special variation among families (Tables 4 and 6). In this sense, partially resistant families were more stable temporally and spatially than was family R1. The instability of resistant slash pine Family R1 (with major gene resistance) to various pathogen inocula (virulence) is similar to that reported for loblolly pine [21].

\section{Conclusions}

Among the inocula in these tests there is evidence for significant pathogenic variation including virulence toward major gene resistance and a selection for virulence. The virulent pathotype(s) was more abundant at some locations, and in one test, increased significantly at all locations with sequential generations of the pathogen. In another instance, inocula from the major gene Family R1 were significantly more virulent on this family. Family R1 was less stable temporally and spatially than other resistant families.

\section{Acknowledgments}

We wish to acknowledge the Forest Biology Research Cooperative and the former Integrated Forest Pest Management Cooperative for their support and Carol Young at the RSC for her aid in data collection. Also we want to thank Rose Kimlinger for her aid in manuscript preparation.

\section{Conflict of Interest}

The authors declare no conflict of interest.

\section{References}

1. Griggs, M.M.; Schmidt, R.A. Increase and Spread of Fusiform Rust. In Proceedings of Management of Fusiform Rust in Southern Pines, Gainesville, FL, USA, 7-8 December 1977; pp. 32-38.

2. Dinus, R.J. Knowledge about Natural Ecosystems as a Guide to Disease Control in Managed Forests. In Proceedings of American Phytopathology Society; American Phytopathological Society: Vancouver, Canada, 1974; pp. 184-190. 
3. Schmidt, R.A. Diseases in Forest Ecosystems: The Importance of Functional Diversity. In Plant Disease: An Advanced Treatise. Vol. II. How Disease Develops in Populations; Horsfall, J.G., Cowling, E.B., Eds.; Academic Press: New York, NY, USA, 1978; pp. 187-315.

4. Pye, J.M.; Wagner, J.E.; Holmes, T.P.; Cubbage, F.W. Positive Returns from Investment in Fusiform Rust Research; U. S. Department of Agriculture, Forest Service, Southern Research Station: Asheville, NC, USA, 1997; p. 55.

5. Schmidt, R.A. Fusiform rust of southern pines: A major success story for forest disease management. Phytopathology 2003, 93, 1048-1051.

6. Kuhlman, E.G. Frequency of single-gall isolates of Cronartium quercuum F. sp. fusiforme with virulence toward three resistant loblolly pine families. Phytopathology 1990, 80, 614-617.

7. Powers, H.R., Jr. The use of survivors of artificial inoculation tests in developing fusiform rust resistant seed orchards. Phytopathol. Medit. 1980, 19, 17-20.

8. Snow, G.A.; Dinus, R.J.; Kais, A.G. Variation in pathogenicity of diverse sources of Cronartium fusiforme on selected slash pine families. Phytopathology 1975, 65, 170-175.

9. Snow, G.A.; Kais, A.G. Pathogenic variability in isolates of Cronartium fusiforme from five southern states. Phytopathology 1970, 60, 1730-1731.

10. Wilcox, P.L.; Amerson, H.V.; Kuhlman, E.G.; Liu, B.H.; O’Malley, D.M.; Sederoff, R.R. Detection of a Major Gene for Resistance to Fusiform Rust Disease in Loblolly Pine by Genomic Mapping. Proc. Natl. Acad. Sci. USA 1996, 93, 3859-3864.

11. Nelson, C.D.; Doudrick, R.L.; Nance, W.L.; Hamaker, J.M.; Capo, B. Specificity of Host: Pathogen Genetic Interaction for Fusiform Rust Disease on Slash Pine. In Proceedings of the 22nd Southern Forest Tree Improvement Conference, Atlanta, GA, USA, 14-17 June 1993; pp. 403-410.

12. Kong, X. RAPD Mapping and Its Application to Slash Pine Breeding. Ph.D. Thesis, Texas A \& M University, College Station, TX, USA, 1996.

13. Amerson, H.V. Department of Forestry, North Carolina State University, Raleigh, NC, USA. Personal communication, 2002.

14. Knighten, J.L.; Young, C.H.; McCartney, T.C.; Anderson, R.L. Resistance Screening Center Procedures Manual: A Step-by-Step Guide Used in the Operational Screening of Southern Pines for Resistance to Fusiform Rust; U. S. Department of Agriculture Forest Service: Asheville, NC, USA, 1988; p. 62.

15. Gramacho, K.P. Disease Resistance and Pathogenic Variability in the Fusiform Rust Slash Pine Pathosystem. Ph.D. Thesis, University of Florida, Gainesville, FL, USA, 1999.

16. Walkinshaw, C.H.; Dell, T.R.; Hubbard, S.D. Predicting Field Performance of Slash Pine Families from Inoculated Greenhouse Seedlings; Forest Experiment Station Research Paper SO-160U; U. S. Department of Agriculture Forest Service South: Asheville, NC, USA, 1980.

17. Schmidt, R.A.; Goddard, R.E. Preliminary Results of Fusiform Rust Resistance from Field Progeny Tests of Selected Slash Pines. In Proceedings of the Eleventh Conference of Southern Forest Tree Improvement, Atlanta, GA, USA, 11-12 June 1971; pp. 37-44.

18. Sohn, S.I.; Goddard, R.E.; Schmidt, R.A. Comparative Performances of Slash Pine for Fusiform Rust Resistance in High Rust Hazard Locations. In Proceedings of the Thirteenth Forest Tree Improvement Conference, Raleigh, NC, USA, 10-11 June 1975; pp. 204-211. 
19. Goddard, R.E.; Schmidt, R.A. Early Identification of Rust-Resistant Slash Pine through Controlled Inoculations. In Proceedings of the Eleventh Conference of Southern Forest Tree Improvement, Atlanta, GA, USA, 11-12 June 1971; pp. 31-36.

20. Schmidt, R.A.; Gramacho, K.P.; Miller, T.; Young, C.H. Components of partial resistance in the slash pine-Fusiform rust pathosystem. Phytopathology 2000, 90, 1005-1010.

21. Isik, F.; Amerson, H.V.; Whetten, R.W.; Garcia, S.A.; McKeand, S.E. Interaction of Fr genes and mixed-pathogen inocula in the loblolly pine-fusiform rust pathosystem. Tree Genet. Genomes 2012, $8,15-25$.

(C) 2013 by the authors; licensee MDPI, Basel, Switzerland. This article is an open access article distributed under the terms and conditions of the Creative Commons Attribution license (http://creativecommons.org/licenses/by/3.0/). 